Prepared in cooperation with the National Park Service and the University of Wisconsin-La Crosse

\title{
Lake Levels and Water Quality in Comparison to Fish Mercury Body Burdens, Voyageurs National Park, Minnesota, 2013-15
}
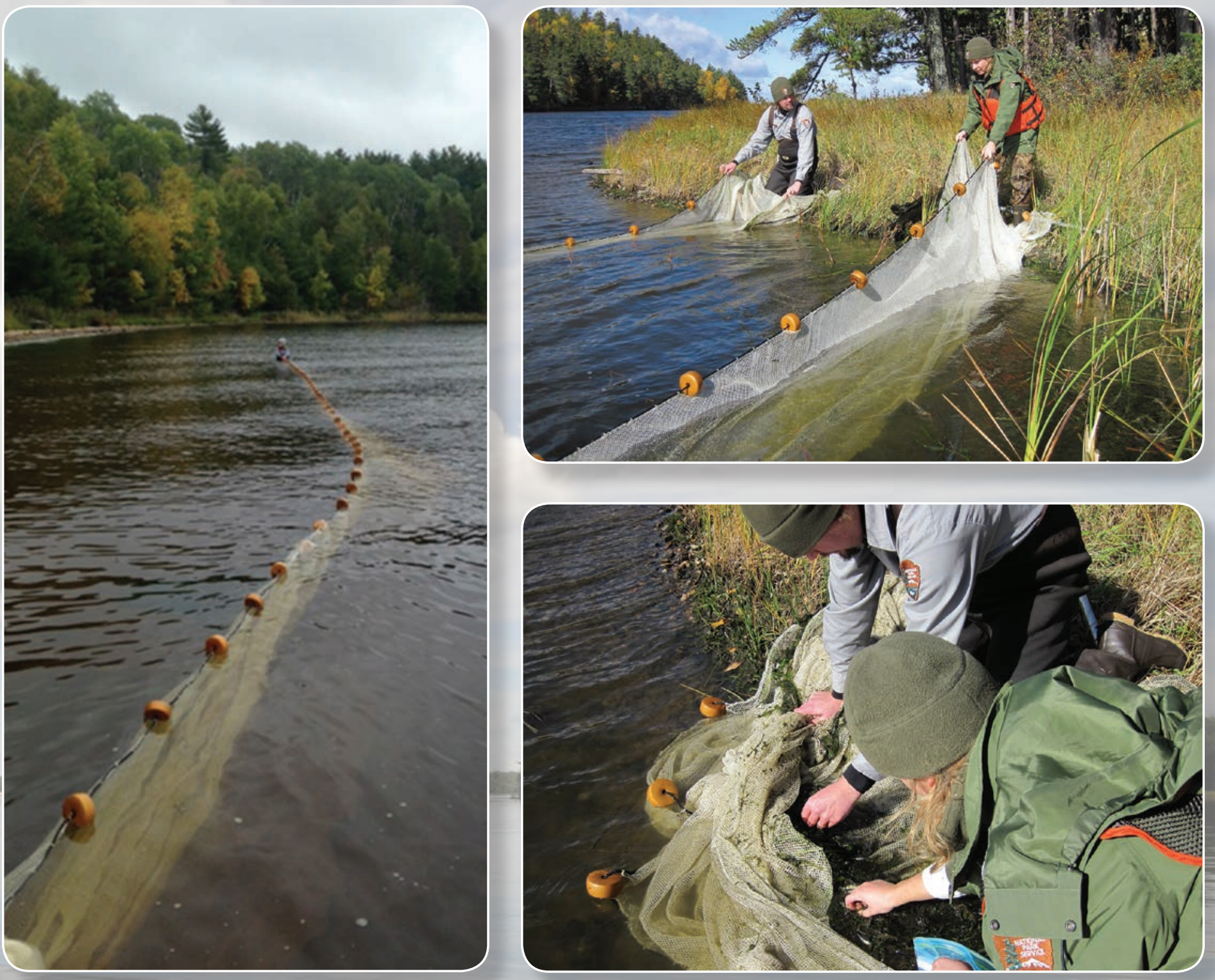

Scientific Investigations Report 2016-5175

U.S. Department of the Interior

U.S. Geological Survey 


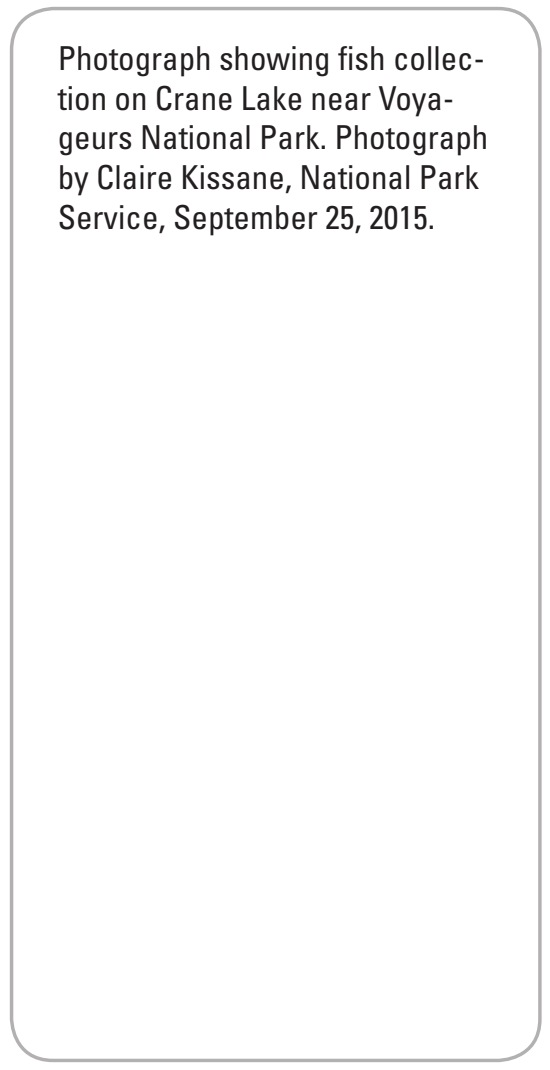

Photograph showing National Park Service personnel capturing yellow perch on Kabetogama Lake, Voyageurs National Park. Photograph by Craig Treat, National Park Service, September 29, 2010.

Photograph showing National Park Service personnel capture yellow perch on Kabetogama Lake, Voyageurs National Park. Photograph by Craig Treat, National Park Service, September 29, 2010.

Front cover photograph descriptions.

Photograph showing a scenic lake view in Voyageurs National Park. Photograph by Geoffrey Smith, August 25, 2011.

Back cover photograph description. 


\section{Lake Levels and Water Quality in Comparison to Fish Mercury Body Burdens, Voyageurs National Park, Minnesota, 2013-15}

By Victoria G. Christensen, James H. Larson, Ryan P. Maki, Mark B. Sandheinrich, Mark E. Brigham, Claire Kissane, and Jaime F. LeDuc

Prepared in cooperation with the National Park Service and the University of Wisconsin-La Crosse

Scientific Investigations Report 2016-5175 


\title{
U.S. Department of the Interior SALLY JEWELL, Secretary
}

\section{U.S. Geological Survey Suzette M. Kimball, Director}

\author{
U.S. Geological Survey, Reston, Virginia: 2017
}

For more information on the USGS - the Federal source for science about the Earth, its natural and living resources, natural hazards, and the environment—visit http://www.usgs.gov or call 1-888-ASK-USGS.

For an overview of USGS information products, including maps, imagery, and publications, visit http://store.usgs.gov/.

Any use of trade, firm, or product names is for descriptive purposes only and does not imply endorsement by the U.S. Government.

Although this information product, for the most part, is in the public domain, it also may contain copyrighted materials as noted in the text. Permission to reproduce copyrighted items must be secured from the copyright owner.

Suggested citation:

Christensen, V.G., Larson, J.H., Maki, R.P., Sandheinrich, M.B., Brigham, M.E., Kissane, Claire, and LeDuc, J.F., 2017, Lake levels and water quality in comparison to fish mercury body burdens, Voyageurs National Park, Minnesota, 2013-15: U.S. Geological Survey Scientific Investigations Report 2016-5175, 17 p., https://doi.org/10.3133/ sir20165175.

ISSN 2328-0328 (online) 


\section{Contents}

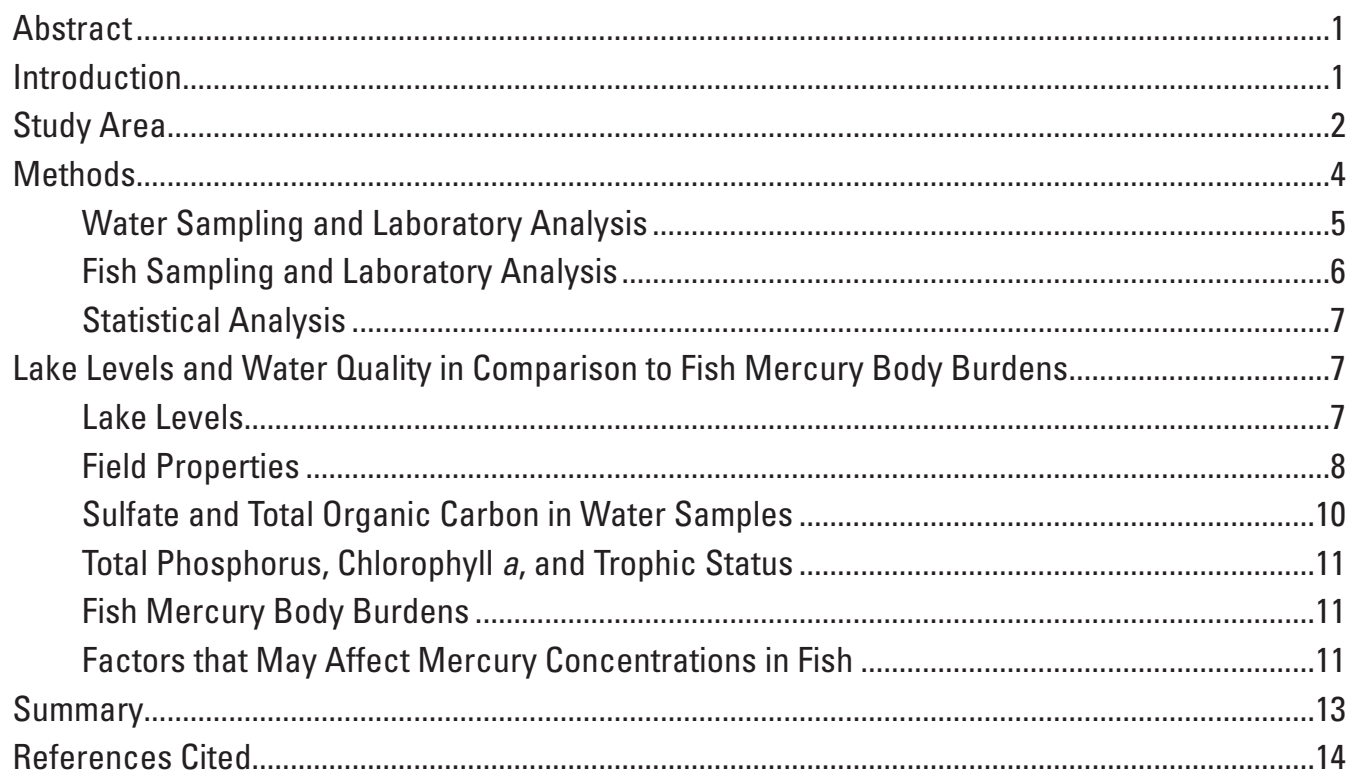

\section{Figures}

1. Map showing location of study area, nearshore fish collection and water-quality sampling sites, and midlake water-quality sampling sites in Voyageurs National Park, northern Minnesota ..............................................................................................

2. Graph showing the 2000 Rule Curves or maximum and minimum water levels for Namakan Reservoir and Rainy Lake, Minnesota .

3. Graph showing water levels and water-level fluctuations, Namakan Reservoir and Rainy Lake, Voyageurs National Park, 1970-2015.

\section{Tables}

1. Description of midlake and nearshore sampling sites, Voyageurs National Park, Minnesota, 2013-15.

2. Constituent concentrations and relative percent differences in field blank and replicate water samples collected from Voyageurs National Park, Minnesota, 2013-15

3. Median values of selected field properties in water samples, Voyageurs National Park, 2013-15.

4. Median concentrations of dissolved sulfate, total organic carbon, total phosphorus, and chlorophyll $a$ in water samples, Voyageurs National Park, 2013-15.

5. Median concentrations of total mercury in young-of-the-year yellow perch samples from nearshore sites, Voyageurs National Park, 2013-15. 


\section{Conversion Factors}

\begin{tabular}{lcl}
\multicolumn{2}{l}{ International System of Units to U.S. customary units } & \\
\hline & \multicolumn{1}{c}{ Byltiply } & To obtain \\
\hline millimeter (mm) & Length & \\
meter (m) & 0.03937 & inch (in.) \\
& 3.281 & foot (ft) \\
\hline gram (g) & Mass & \\
milligram (mg) & 0.03527 & ounce, avoirdupois (oz) \\
\hline
\end{tabular}

\section{Supplemental Information}

Temperature in degrees Celsius $\left({ }^{\circ} \mathrm{C}\right)$ may be converted to degrees Fahrenheit $\left({ }^{\circ} \mathrm{F}\right)$ as ${ }^{\circ} \mathrm{F}=\left(1.8 \times{ }^{\circ} \mathrm{C}\right)+32$.

Specific conductance is given in microsiemens per centimeter at 25 degrees Celsius $(\mu \mathrm{S} / \mathrm{cm}$ at $\left.25^{\circ} \mathrm{C}\right)$.

Concentrations of chemical constituents in water are given in either milligrams per liter (mg/L) or micrograms per liter ( $\mu \mathrm{g} / \mathrm{L})$.

Concentrations of mercury in fish are given in milligrams per kilogram $(\mathrm{mg} / \mathrm{kg})$ or nanograms per $\operatorname{gram}(\mathrm{ng} / \mathrm{g})$.

\section{Datum}

Vertical coordinate information is referenced to the North American Vertical Datum of 1988 (NAVD 88).

Horizontal coordinate information is referenced to the North American Datum of 1983 (NAD 83).

Elevation, as used in this report, refers to distance above the vertical datum.

\section{Abbreviations}

$\begin{array}{ll}\text { DOC } & \text { dissolved organic carbon } \\ \text { EPA } & \text { U.S. Environmental Protection Agency } \\ \text { IJC } & \text { International Joint Commission } \\ \text { NPS } & \text { National Park Service } \\ p \text {-value } & \text { probability value } \\ \text { TOC } & \text { total organic carbon } \\ \text { USGS } & \text { U.S. Geological Survey }\end{array}$




\title{
Lake Levels and Water Quality in Comparison to Fish Mercury Body Burdens, Voyageurs National Park, Minnesota, 2013-15
}

\author{
By Victoria G. Christensen, ${ }^{1}$ James H. Larson, ${ }^{1}$ Ryan P. Maki, ${ }^{2}$ Mark B. Sandheinrich, ${ }^{3}$ Mark E. Brigham, ${ }^{1}$ Claire \\ Kissane, ${ }^{2}$ and Jaime F. LeDuc ${ }^{2}$
}

\section{Abstract}

Within Voyageurs National Park in Minnesota, lake levels are controlled by a series of dams to support a variety of uses. Previous research indicates a link between these artificially maintained water levels, referred to as rule curves, and mercury concentrations in fish owing to the drying and rewetting of wetlands and other nearshore areas, which may release methylmercury into the water when inundated. The U.S. Geological Survey, National Park Service, and University of Wisconsin-La Crosse cooperated in a study to assess the importance of lake-level fluctuation and other factors affecting mercury concentrations in Perca flavescens (yellow perch) in the lakes of Voyageurs National Park. For this study, mercury body burdens were determined for young-of-the-year yellow perch collected from the large lakes within Voyageurs National Park during 2013-15. These mercury body burdens were compared to lake levels and water-quality constituents from the same period.

Field properties and profiles of lake water quality indicated that Sand Point, Little Vermilion, and Crane Lakes were anoxic at times near the lake bottom sediments, where sulfatereducing bacteria may convert mercury to methylmercury. The median dissolved sulfate concentration was highest in Crane Lake, the median total organic carbon concentration was highest in Sand Point Lake, and the median total phosphorus concentration was highest in Kabetogama Lake, all of which is consistent with previous research. All lakes had median chlorophyll $a$ concentrations of 3.6 micrograms per liter or less with the exception of Kabetogama Lake, where the median concentrations were 4.3 micrograms per liter for the midlake sites and 7.1 micrograms per liter and 9.0 micrograms per liter for the nearshore sites.

Mercury concentrations in sampled fish varied widely between years and among lakes, from 14.7 nanograms per gram in fish samples from Kabetogama Lake in 2015 to

\footnotetext{
${ }^{1}$ U.S. Geological Survey.
}

${ }^{2}$ National Park Service.

${ }^{3}$ University of Wisconsin-La Crosse.
178 nanograms per gram in fish samples from Crane Lake in 2014. Data from this study can be combined with ongoing hydrologic modeling studies to evaluate trends in the mercury body burden of fish and different water-level management scenarios prescribed by the 2000 Rule Curves and the 1970 Rule Curves.

\section{Introduction}

Major sources of mercury to the aquatic environment include erosion of geologic material, urban discharges, industrial discharges, agriculture, mining, and atmospheric deposition (Wang and others, 2004; Pirrone and others, 2009). In many aquatic ecosystems around the world, atmospheric deposition of mercury and subsequent conversion to methylmercury in water bodies has led to elevated fish mercury body burdens (Driscoll and others, 2013). In North America, atmospheric deposition of methylmercury in recreational and commercial fisheries is a concern because of risks to both human and wildlife health (Wiener and others, 2013; Driscoll and others, 2007, 2013). Methylmercury biomagnifies in aquatic food webs (Watras and Bloom, 1992; Morel and others, 1998), potentially reaching concentrations sufficient to induce sublethal, toxic effects in wildlife (Meyer and others, 1998; Sandheinrich and Wiener, 2011; Depew and others, 2012) and humans who routinely consume fish with high mercury concentrations (Shubat and others, 1995); therefore, in 2001 the U.S. Environmental Protection Agency (EPA) issued a criterion of 0.3 milligram methylmercury per kilogram fish tissue wet weight $(\mathrm{mg} / \mathrm{kg})$ for the protection of human health (U.S. Environmental Protection Agency, 2001), which is the equivalent of 300 nanograms per gram (ng/g).

In Minnesota, fish in many lakes have high mercury concentrations (Glazer and Bohlander, 1978; Wiener and others, 2006). This is especially true in sensitive ecosystems, such as wetlands or lakes with hydrologically connected wetlands, because biogeochemical conditions in wetlands tend to favor the bacterial conversion of inorganic mercury to methylmercury (Wiener and others, 2006; Driscoll and others, 2007). 
Sorensen and others (2005) provide evidence that waterlevel fluctuations in 13 lakes in northern Minnesota, including the large lakes in Voyageurs National Park, were highly correlated with the methylmercury concentrations found in young-of-the-year Perca flavescens (yellow perch) collected at the end of the growing season each fall, indicating a possible link between artificial lake-level management and fish mercury body burdens. In a followup study on a subset of the lakes studied by Sorensen and others (2005), Larson and others (2014) determined that relations between mercury concentrations in fish and water level varied substantially among lakes. Drying and rewetting cycles within wetlands or impoundments has been correlated with elevated mercury in fish (Snodgrass and others, 2000) and elevated methylmercury in water (Brigham and others, 2002). Other factors, such as trophic status (Pickardt and others, 2002), wetland morphology (Snodgrass and others, 2000), and sulfate concentrations (Sorenson and others, 2005), also can affect mercury bioavailability to fish.

The water levels in the large lakes in Voyageurs National Park (fig. 1) are controlled by a series of dams that were completed to support a variety of legally recognized uses of these lakes. Because these lakes are international waters, the International Joint Commission (IJC) has regulatory authority and stipulates water-management practices (rule curves) for the private-sector dam operators. In 2000, the IJC changed the rules governing dam operation (International Joint Commission, 2001). Rule curves are bands of allowable high and low water levels throughout the year. The rule curves (fig. 2) were expected to restore water levels to conditions similar to predam conditions for Namakan Reservoir (which includes Kabetogama Lake, Namakan Lake, Sand Point Lake, Crane Lake, and Little Vermillion Lake).

The magnitude of observed water-level fluctuations during 1970-99 was significantly greater than observed waterlevel fluctuations during 2000-09 in Namakan Reservoir (Christensen and others, 2011). Water-level fluctuation has been linked to water quality and aquatic biological effects in these lakes (Christensen and others, 2013; Cole, 1979, 1982; Kallemeyn and others, 1993); therefore, a better understanding of lake levels and water quality in comparison to fish mercury body burdens was needed. To address this need, the U.S. Geological Survey (USGS), National Park Service (NPS), and University of Wisconsin-La Crosse cooperated in a study to assess the importance of lake-level fluctuation and other factors affecting mercury concentrations in yellow perch in six lakes in Voyageurs National Park during 2013-15. This assessment of factors suspected of having an effect on concentrations of mercury in fish will contribute to the IJC's body of knowledge as a review is performed of information collected regarding the effects of the 2000 Rule Curves on the health of this ecosystem.

The purpose of this report is to characterize the environmental variables, including lake-level fluctuation and other factors, associated with mercury body burdens in young-ofthe-year yellow perch in Rainy Lake and Namakan Reservoir,
Voyageurs National Park, during 2013-15. The data collected as part of this study can be used by the IJC and other researchers in decision-making models related to the effect of water-level changes on mercury body burdens in fish and other environmental factors.

\section{Study Area}

Voyageurs National Park, a water-based park in northern Minnesota on the border between the United States and Canada (fig. 1), is in a mercury sensitive landscape (Knights and others, 2005; Wiener and others, 2016). Voyageurs National Park was established to protect "the outstanding scenery, geological conditions, and waterway system which constituted a part of the historic route of the Voyageurs" (Public Law 91-661). The park protects a series of southern boreal lakes on the Canadian (Precambrian) Shield. The ecosystem health of these lakes is of critical importance for many of the recreational uses of the park and the NPS as it attempts to meet its mission of maintaining resources in an unimpaired condition for future generations.

Rainy Lake and Namakan Reservoir are two of the most popular fishing destinations in northern Minnesota; visitors spend an average of more than 700,000 hours per year angling in these waters (Kallemeyn and others, 2003). Fishing is the principal recreational activity in Voyageurs National Park (Kallemeyn and others, 2003), making consumption of fish with high mercury body burdens a potential health risk to visitors.

In the lakes in Voyageurs National Park, a high proportion of deposited mercury is methylated, leading to high concentrations of toxic methylmercury in fish (Wiener and others, 2006, 2013). Mercury concentrations in Esox lucius (northern pike) from four Voyageurs National Park lakes sampled during 2000-11 were greater than levels that can have negative reproductive effects on native fish species (Sandheinrich and Wiener, 2011; Wiener and others, 2013, 2016), and the highest mercury concentrations measured for northern pike sampled in Minnesota were in samples collected in two Voyageurs National Park lakes (Wiener and others, 2006). Mercury body burdens of fish in Voyageurs National Park lakes are greater than levels shown to cause sublethal and reproductive effects in fish. Seventy percent of fish sampled in a recent study had mercury concentrations exceeding fish consumption guidelines, whereas 94 percent exceeded the tissue residue criterion set by the EPA (U.S. Environmental Protection Agency, 2001; National Park Service, 2012); therefore, mercury body burdens of fish continue to be a top management concern and necessitate consumption advisories for all sampled Voyageurs National Park lakes (National Park Service, 2012), which are listed for mercury impairment on Minnesota's Impaired Waters Inventory (Minnesota Pollution Control Agency, 2016).

Water-level fluctuations in Voyageurs National Park have a tremendous effect on aquatic ecosystem health (Kallemeyn 


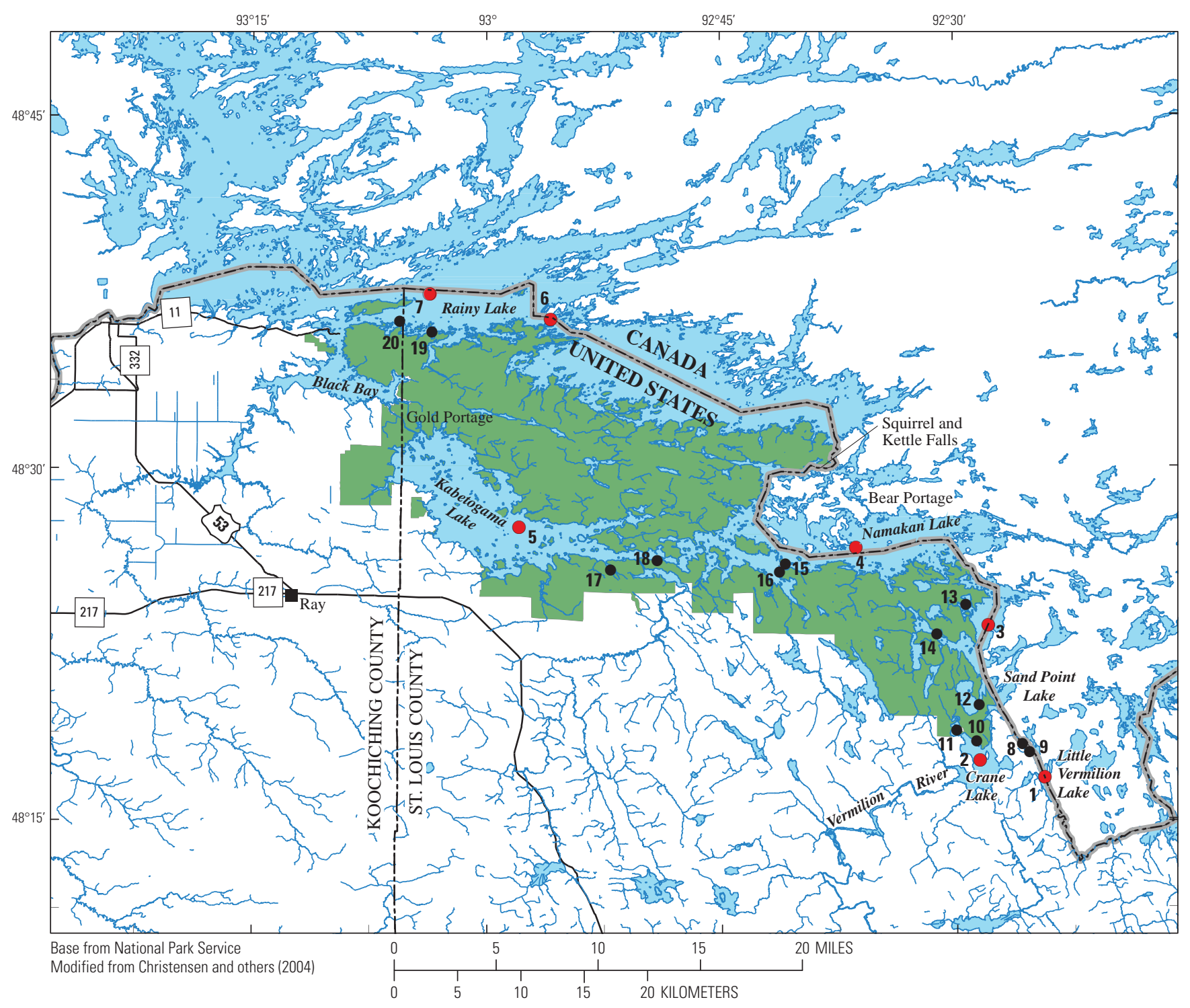

EXPLANATION

Voyageurs National Park

11 Nearshore fish collection and water-quality sampling site-Number is site identifier from table 1

3 Midlake water-quality sampling site-Number is site identifier from table 1

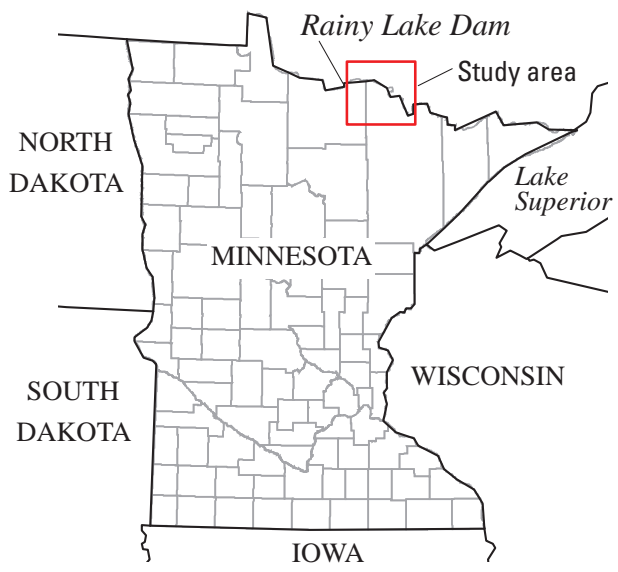

Figure 1. Location of study area, nearshore fish collection and water-quality sampling sites, and midlake water-quality sampling sites in Voyageurs National Park, northern Minnesota. 


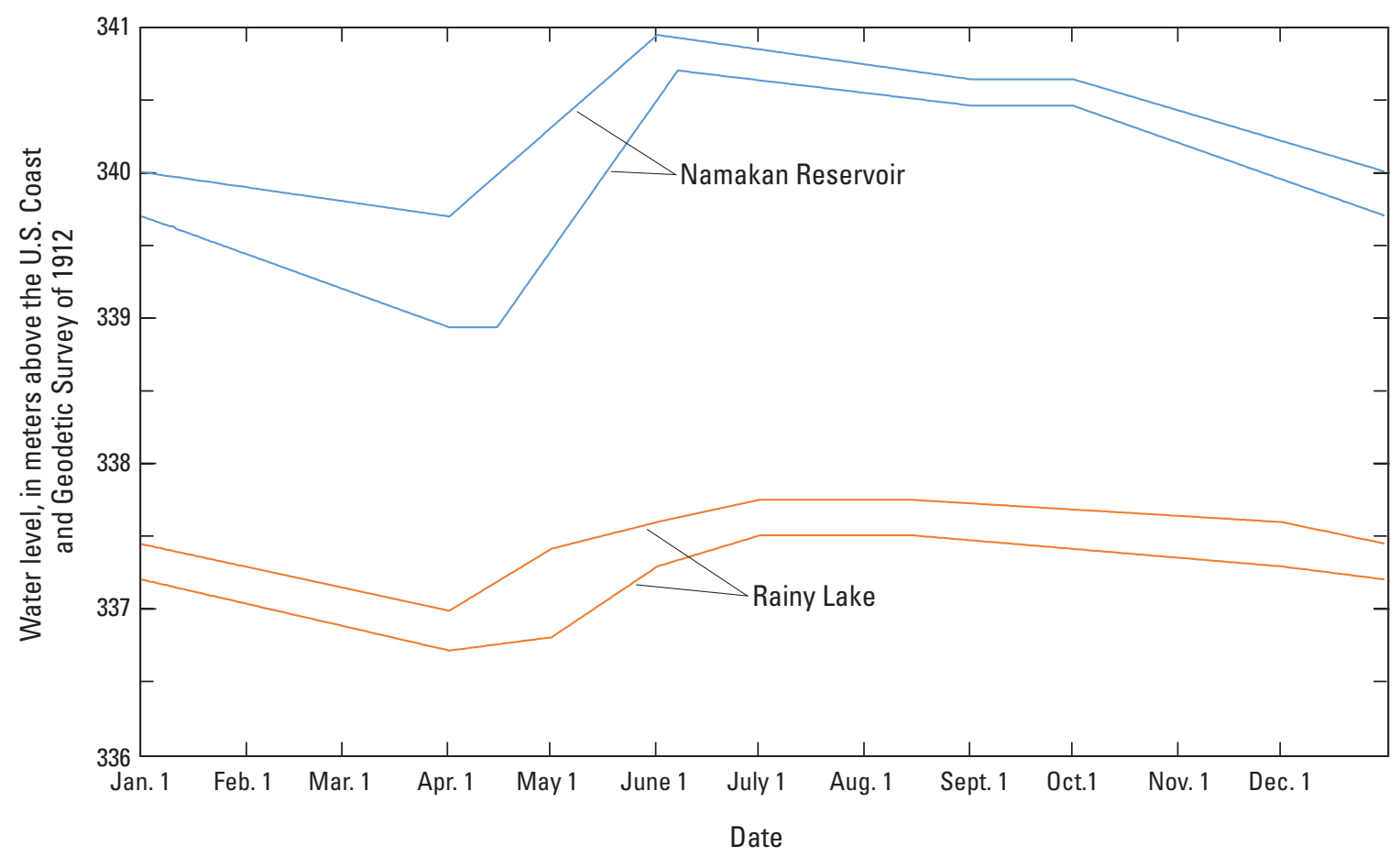

Figure 2. The 2000 Rule Curves or requisite maximum and minimum water levels for Namakan Reservoir and Rainy Lake, Minnesota. These are the range in water levels established by the International Joint Commission that the private-sector dam operators are required to maintain throughout the year.

and others, 2003), and resource managers have the ability to affect water-level fluctuations in this system. The water levels in these lakes are controlled by a privately owned hydropower dam at the outlet of Rainy Lake and by regulatory dams at Squirrel and Kettle Falls on Namakan Lake. Water levels have been controlled by the dams on Rainy Lake and Namakan Reservoir since the early 1900s (Kallemeyn and others, 2003). Prior to installation of the dams in the early 1900s, all these lakes were natural water bodies. Flows are now regulated to satisfy multiple uses, including power generation and recreation.

Because some of the lakes of the Namakan Reservoir system are international waters, beginning in 1949, privatesector dam operators have had to maintain lake levels using a series of rule curves established by the IJC (Kallemeyn and others, 2003). In order to better regulate water levels, the IJC modified the rule curves in 1957 and 1970. From 1970 through 1999, the 1970 Rule Curves were in effect, by which larger-than-natural fluctuations in water levels of the Namakan Reservoir were used to maintain smaller-than-natural fluctuations in water levels of Rainy Lake (Kallemeyn and others, 2003). During the 1980s, Voyageurs National Park initiated research on the effects of artificial lake-level management on the aquatic ecosystem of the park to develop alternatives to the 1970 Rule Curves (Kallemeyn and Cole, 1990; Kallemeyn and others, 1993). The International Steering Committee of the IJC made recommendations for rule curve changes in 1993. In January 2000, after studying the recommendations by the International Steering Committee, the IJC issued a new
Supplementary Order for the hydrological management of the Rainy Lake-Namakan Reservoir system; this order prescribes the 2000 Rule Curves. The 2000 Rule Curves specify waterlevel fluctuations that are similar to predam hydrology rather than the water levels specified under the 1970 Rule Curves. The requisite maximum and minimum water levels as defined by the IJC for Namakan Reservoir and Rainy Lake are shown in figure 2 .

\section{Methods}

Young-of-the-year yellow perch were collected from 13 nearshore sites in Voyageurs National Park (table 1). The 13 sites were included in the study by Sorensen and others (2005) and in the current study. A subset, consisting of six of the sites, has been sampled annually since 2001 and was included in the study by Sorensen and others (2005) and the current study (table 1, footnotes 2 and 3). One of those six sites (Sand Point, west side, near Mukooda Lake; Sorensen and others, 2005) has been sampled annually since 1991 (with the exception of 1995).

Water-quality data, including factors known or believed to affect mercury speciation and methylation (such as $\mathrm{pH}$, total organic carbon, and dissolved sulfate) were collected at the 13 nearshore fish collection sites and 7 midlake sites (table 1). Sampling at one of the midlake sites, Rainy Lake east of Drywood Island, was discontinued in 2013. 
The data collected during this study can be compared to historical data to assess whether a change in rules governing dam operation affected mercury body burdens in yellow perch in these lakes. The data collection and interpretation were completed in conjunction with results of other studies assessing the hydrology and bathymetry of these lakes as part of the IJC's efforts to determine the effects of current rules governing dam operation.

\section{Water Sampling and Laboratory Analysis}

Water-quality data were collected by NPS personnel at 7 midlake sites and 13 nearshore sites. The midlake sites and the nearshore sites (collocated with the fish-collection sites) were sampled once per year in September or October 2013, 2014, and 2015.

Field properties of water temperature, Secchi-disk transparency, specific conductance, $\mathrm{pH}$, dissolved oxygen, and acid neutralizing capacity were measured at all midlake and nearshore sites during each sampling event (Wilde and Radtke, 2005). Temperature, specific conductance, $\mathrm{pH}$, and dissolved oxygen were measured at each lake site about 1 meter (m) below the lake surface with a multiparameter sonde calibrated according to USGS methods (Wagner and others, 2006). Secchi-disk transparency was recorded at each site. Because the 13 nearshore sites (fig. 1) were shallow and typically the bottom of the lake is visible, Secchi transparency was measured by moving out into the lake until the Secchi disk was no longer visible at the bottom of the lake. Acid neutralizing capacity was determined on nearshore and midlake water samples by digital titration with a Hach kit in the field laboratory (U.S. Geological Survey, variously dated).

Lake profiles of water temperature, specific conductance, $\mathrm{pH}$, and dissolved oxygen concentration were collected at midlake sites during sampling in 2013-15 with the multiparameter sonde. Profiles were collected generally at 2-m depth

Table 1. Description of midlake and nearshore sampling sites, Voyageurs National Park, Minnesota, 2013-15.

[USGS, U.S. Geological Survey; latitude and longitude are given in DD MM SS, degrees, minutes, and seconds; Minn., Minnesota]

\begin{tabular}{|c|c|c|c|c|}
\hline $\begin{array}{c}\text { Site } \\
\text { identifier } \\
\text { (fig. 1) }\end{array}$ & USGS site number & Site name & Latitude & Longitude \\
\hline \multicolumn{5}{|c|}{ Midlake sites } \\
\hline 1 & 481648092242301 & Little Vermilion Lake east of Dovre Lake & 481648.0 & -922422.6 \\
\hline 2 & 481730092283101 & Crane Lake southwest of Indian Island & 481729.7 & -922831.2 \\
\hline 3 & 482226092283301 & $\begin{array}{l}\text { Sand Point Lake below Harrison Narrows near Crane Lake, } \\
\text { Minn. }\end{array}$ & 482226 & -922833 \\
\hline 4 & 482616092372201 & Namakan Lake near Ray, Minn. & 482616 & -923722 \\
\hline 5 & 482731092574701 & Kabetogama Lake near Grave Island near Ray, Minn. & 482731 & -925747 \\
\hline 6 & 483622092560701 & Rainy Lake at Brule Narrows near International Falls, Minn. & 483622 & -925607 \\
\hline 7 & 483713093035201 & Rainy Lake east of Drywood Island ${ }^{1}$ & 483713.0 & -930352.1 \\
\hline \multicolumn{5}{|c|}{ Nearshore sites } \\
\hline 8 & 481818092254201 & Little Vermilion Lake above Little Vermilion Narrows² & 481815.8 & -922546.6 \\
\hline 9 & 481751092251901 & Little Vermilion Lake, northwest side & 481750.9 & -922518.8 \\
\hline 10 & 481827092285401 & Crane Lake, north shore, near Indian Island² & 481827.4 & -922854.0 \\
\hline 11 & 481835092294401 & Crane Lake, northwest end, near Crane Lake, Minn. & 481835.2 & -922943.9 \\
\hline 12 & 482006092283301 & Sand Point Lake, west side, near Mukooda Lake & 482005.8 & -922833.3 \\
\hline 13 & 482416092290401 & Sand Point Lake at Swansons Bay & 482416.3 & -922903.6 \\
\hline 14 & 482241092311501 & Sand Point Lake at Grassy Bay & 482252.9 & -923115.0 \\
\hline 15 & 482553092404801 & Namakan Lake at Wolf Pack Islands² & 482553.2 & -924047.2 \\
\hline 16 & 482541092411601 & Namakan Lake at McManus Island & 482540.9 & -924115.7 \\
\hline 17 & 482556092521601 & Kabetogama Lake at Blind Ash Bay² & 482555.5 & -925215.5 \\
\hline 18 & 482603092490501 & Kabetogama Lake below Boblore Island & 482603.4 & -92495.1 \\
\hline 19 & 483549093033001 & Rainy Lake, south side, near Diamond Island² & 483548.9 & -930330.0 \\
\hline 20 & 483615093054001 & Rainy Lake near Dove Bay & 483615.2 & -930540.2 \\
\hline
\end{tabular}


intervals, except at Rainy Lake at Brule Narrows (USGS site number 483622092560701), where the intervals were $1 \mathrm{~m}$.

Water samples for laboratory analysis of dissolved sulfate, total organic carbon, total phosphorus, and chlorophyll $a$ were collected from nearshore and midlake sites by NPS personnel using a Van Dorn-type sampler, according to methods described by Payne (1991). Water samples were placed on ice and shipped to the USGS National Water Quality Laboratory in Denver, Colorado, for analysis of dissolved sulfate (Fishman and Friedman, 1989) and total organic carbon (Clesceri and others, 1998) and to the Natural Resources Research Institute Laboratory in Duluth, Minnesota, for analysis of total phosphorus by persulfate digestion (American Public Health Association, 1999) and chlorophyll $a$ (Arar and Collins, 1997).

All field personnel were familiarized with quality-assurance techniques to ensure sample integrity. The techniques include maintaining field instruments according to manufacturers' guidelines, properly storing calibration standards, recording field measurements in the field, cleaning all field sampling equipment before use according to the USGS National Field Manual guidelines (U.S. Geological Survey, variously dated), and collecting and analyzing quality-control samples to document the variability associated with sample collection. Field blanks and field replicates (table 2) were collected and analyzed each season (10 quality-control samples [5 replicates and 5 blanks] out of 32 environmental samples, or about 31 percent). Field blanks were processed under the same conditions as the environmental samples. Field replicates were split from the environmental samples. Water samples were collected at times of the year when samples were historically collected to ensure comparability of data while minimizing the spatial and seasonal differences in the dataset.
Field blank constituent concentrations were generally less than the laboratory reporting level for 6 of the 10 constituent analyses (table 2). Relative percent differences between the replicate pairs were generally low with the exception of total phosphorus in one sample collected on September 21, 2015, which had a relative percent difference of 50, and chlorophyll $a$, which had a range of 21-60 during 2013-15. Chlorophyll $a$ concentrations are spatially variable and previous studies have also had high relative percent differences between replicate pairs of chlorophyll $a$ samples (Christensen and others, 2004).

\section{Fish Sampling and Laboratory Analysis}

Young-of-the-year yellow perch were sampled once during fall in each of 3 years-2013, 2014, and 2015. NPS personnel collected about 20 yellow perch at each nearshore site-2 sites in Rainy, Kabetogama, Namakan, Little Vermilion, and Crane Lakes and 3 sites in Sand Point Lake (fig. 1). When more than 20 fish were captured at a site, a maximum of 20 fish were analyzed per site. A maximum of 40 fish were analyzed per lake, with the exception of Sand Point Lake where the maximum was 60 .

Samples were collected by shoreline seining. Fish were immediately euthanized using tricaine methanesulfonate (MS-222) and then put on ice. Fish were kept on ice in coolers and transferred to a lakeside laboratory. In the laboratory, the water containing MS-222 was poured out of the fish sample bags, and then deionized water was added. The fish samples were put into a freezer until laboratory analysis. Total length was used to identify presumed young-of-the-year yellow perch in the field, and age of fish kept for mercury analysis was verified in the laboratory by inspection of scales prior to analysis

Table 2. Constituent concentrations and relative percent differences in field blank and replicate water samples collected from Voyageurs National Park, Minnesota, 2013-15

[mg/L, milligram per liter; $\mu \mathrm{g} / \mathrm{L}$, microgram per liter; --, not analyzed; <, less than; NA, not applicable]

\begin{tabular}{|c|c|c|c|c|c|c|c|c|}
\hline \multirow{2}{*}{ Constituent } & \multirow{2}{*}{$\begin{array}{c}\text { Laboratory } \\
\text { repoting } \\
\text { level }\end{array}$} & \multicolumn{7}{|c|}{ Date sampled } \\
\hline & & $10 / 21 / 2013$ & $10 / 22 / 2013$ & $10 / 28 / 2013$ & $10 / 9 / 2014$ & $10 / 15 / 2014$ & 9/21/2015 & $9 / 28 / 2015$ \\
\hline \multicolumn{9}{|c|}{ Field blanks-Concentrations } \\
\hline Dissolved sulfate (mg/L) & 0.02 & 0.02 & -- & -- & $<0.02$ & -- & -- & -- \\
\hline Total organic carbon (mg/L) & 0.7 & -- & -- & -- & $<0.7$ & -- & -- & -- \\
\hline Total phosphorus (mg/L) & 0.002 & $<0.002$ & -- & -- & -- & 0.003 & $<0.002$ & 0.029 \\
\hline Chlorophyll $a(\mu g / L)$ & 0.050 & $<0.500$ & -- & -- & -- & -- & 0.1 & $<0.050$ \\
\hline \multicolumn{9}{|c|}{ Field replicates_-Relative percent difference ${ }^{1}$} \\
\hline Dissolved sulfate & NA & -- & -- & 0 & 5 & -- & -- & -- \\
\hline Total organic carbon & NA & -- & -- & 0 & 0.8 & -- & -- & -- \\
\hline Total phosphorus & NA & -- & 8 & 0 & -- & -- & 50 & 14 \\
\hline Chlorophyll $a$ & NA & -- & 60 & -- & -- & -- & 58 & 21 \\
\hline
\end{tabular}

${ }^{1}$ The relative percent difference is the difference between the environmental sample and a replicate collected at the same time. The relative percent difference was calculated as the difference between the concentration of the replicate sample and the concentration of the environmental sample divided by the mean concentration of the replicate and environmental sample multiplied by 100. 
for mercury. The fish were collected following methods of Sorensen and others (2005).

In the laboratory, each yellow perch was thawed, measured (total length to the nearest millimeter), and weighed (to 0.001 gram). Each fish was placed into a labeled, zipseal plastic bag and stored in a domestic chest freezer until lyophilization to a nearly constant mass (change in dry mass less than 1 percent after 24 hours of additional lyophilization). After lyophilization, each whole fish was homogenized in a soap-washed, stainless steel blender, and the homogenate was stored in a food-grade, zip-seal plastic bag in a desiccator until analyzed for total mercury.

The concentration of total mercury in each whole fish was determined by direct mercury analysis, following EPA Method 7473 (U.S. Environmental Protection Agency, 2007). A 40- to 50-milligram sample of dried, homogenized whole fish was weighed into quartz boats and analyzed directly by thermal decomposition and atomic absorption spectroscopy with an automated Milestone (Shelton, Connecticut) DMA-80 Direct Mercury Analyzer. Mercury concentrations in fish were not blank corrected. The detection limit of the instrument (3 times the standard deviation of mass of mercury in 10 blanks divided by the mean sample mass) was 0.53 nanograms mercury per gram of wet fish (ng/g). The limit of quantification (10 times the standard deviation of mass of mercury in 10 blanks divided by the mean sample mass) was $1.77 \mathrm{ng} / \mathrm{g}$.

Moisture content was determined by difference (thawed fish mass minus lyophilized fish mass) and was used to convert mercury concentrations to units of nanograms per gram (fish-mercury concentrations are most commonly expressed in wet-weight units). Precision and accuracy of total mercury concentrations measured for samples were quantified by the analyses of (1) analytical and procedural blanks, (2) replicate samples, (3) certified reference materials from the National Institute of Standards and Technology and the National Research Council of Canada, and (4) spiked samples.

Mean spike recovery for fish samples collected in 2013 ranged from 93.3 to 102 percent, whereas the mean relative standard deviation ranged from 4.89 to 10.4 percent. Results for quality-control of 2014 and 2015 samples were similar with mean spike recoveries ranging from 91.3 to 109 percent and mean relative standard deviation ranging from 2.5 to 9.55 percent. All blank concentrations were less than the limit of quantification of $1.77 \mathrm{ng} / \mathrm{g}$.

\section{Statistical Analysis}

Wilcox rank sum tests and two-sided seasonal tests (Helsel and Hirsch, 1992) were used to test for differences in water-level fluctuations before and after implementation of the 2000 water-level management plan. The nonnormally distributed data justified the use of nonparametric tests (Helsel and Hirsch, 1992). All statistical tests used a significance level of 0.05 ; statistical significance was indicated for a probability value ( $p$-value) of less than 0.05 .

\section{Lake Levels and Water Quality in Comparison to Fish Mercury Body Burdens}

Lake-level fluctuations and water quality were compared with mercury body burdens in young-of-the-year yellow perch from Rainy Lake and Namakan Reservoir, Voyageurs National Park, for the period 2013-15. A synopsis is provided of the assessment of factors suspected of having an effect on concentrations of mercury in fish.

\section{Lake Levels}

The 2000 Rule Curves were expected to restore a more natural water regime that would affect water levels, water quality, trophic status, and other environmental conditions in Voyageurs National Park. Lake-level data (1970-2015) from the USGS (Gold Portage Outlet from Kabetogama Lake near Ray, MN, site number 05129290; U.S. Geological Survey, 2016), Water Survey Canada, and U.S. Army Corps of Engineers were compiled by, and obtained from, the Lake of the Woods Control Board (Matt De Wolfe, written commun., April 22, 2016). Lake-level data for Namakan Reservoir at Gold Portage on the west end of Kabetogama Lake and at Squirrel and Kettle Falls on the northern side of Namakan Lake (fig.1) during the study period are shown in figure 3 .

Extreme hydrologic events have affected water levels, which sometimes exceeded the upper rule curves after 2000 (Christensen and others, 2004, 2011; Faveri and others, 2015). Previous studies indicated that observed annual waterlevel fluctuations prior to 2000 were significantly greater than observed annual water-level fluctuations after 2000 for Namakan Reservoir (Christensen and others, 2011). A Wilcoxon rank sum test was conducted with the current dataset (fig. 3), and observed annual water-level fluctuations were significantly lower after 2000 ( $p$-value less than 0.0001). This significant decrease in water-level fluctuations after the implementation of the 2000 water-level management plan occurred despite an increase in frequency of extreme hydrologic events in this system after 2000 (Christensen and others, 2004, 2011; Faveri and others, 2015). The difference in the annual waterlevel fluctuations between the two time periods (prior to 2000 and after 2000) appears to be the result of a substantial increase in the minimum water level (Christensen and others, 2011).

During 2013-15, the rule curve maximums for Namakan Reservoir were exceeded from May 12, 2013, to July 7, 2013, by as much as $0.32 \mathrm{~m}$ and again on May 12, 2015, through July 7, 2015, by a maximum of $0.33 \mathrm{~m}$. Minor exceedances also occurred on a few days in fall 2013 and fall 2015. Water levels were less than the lower rule curve on 1 day during the study period, July 11, 2014, by less than $0.01 \mathrm{~m}$. Water-level exceedances are important to note for this study because nearshore areas may become inundated and release methylmercury 


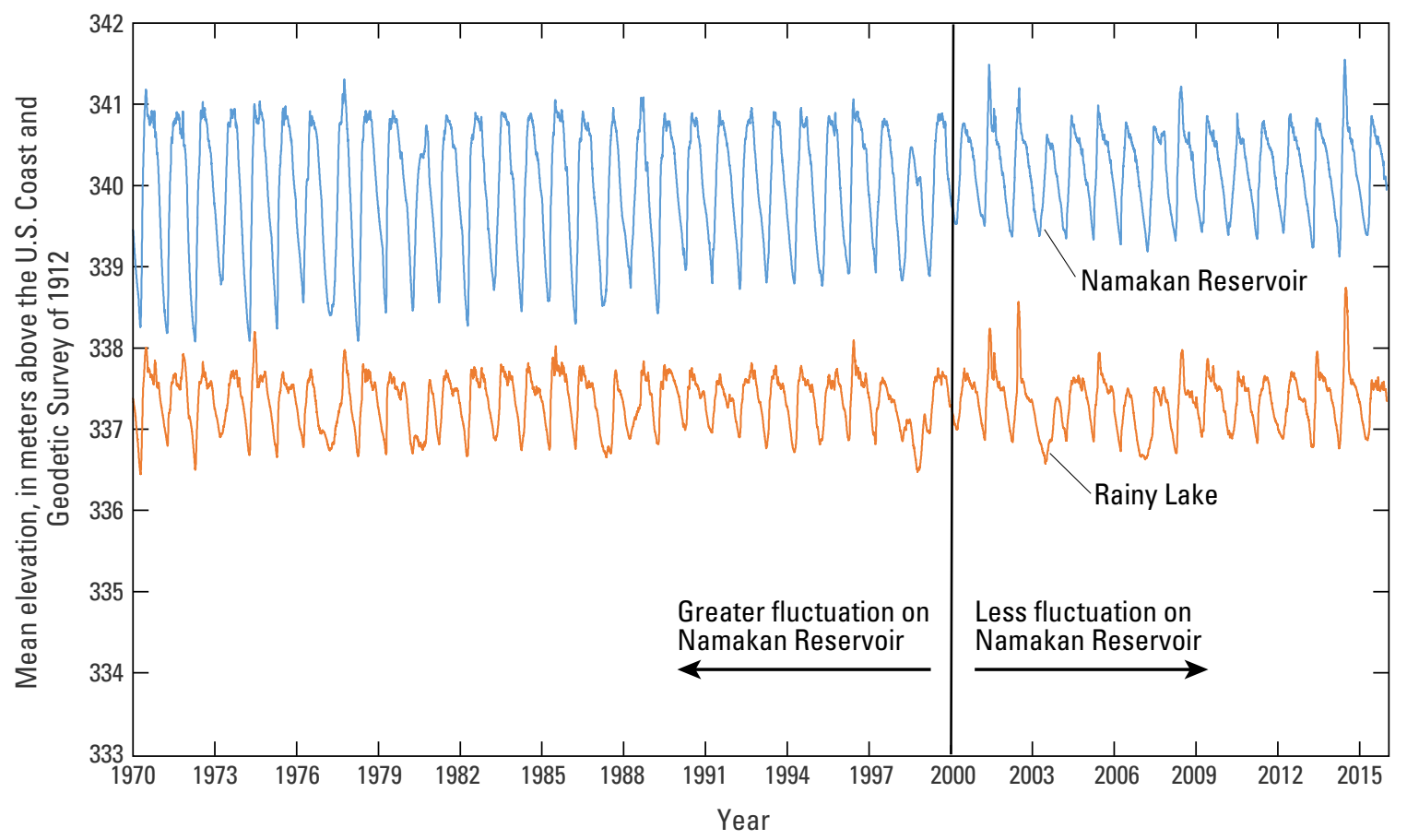

Figure 3. Water levels and water-level fluctuations, Namakan Reservoir and Rainy Lake, Voyageurs National Park, 1970-2015. Data from Lake of the Woods Control Board (Matt De Wolfe, written commun., April 22, 2016).

into the water. The wetlands surrounding these lakes may provide the ideal conditions for mercury methylation, as other researchers have documented in similar forest ecosystems (Driscoll and others, 2007).

\section{Field Properties}

Field properties of water temperature, Secchi-disk transparency, specific conductance, $\mathrm{pH}$, dissolved oxygen, and acid neutralizing capacity were measured at all midlake and nearshore sites during 2013-15. The median values of the field properties measured during the three sampling events are shown in table 3 . All field properties collected for this study are available from the USGS National Water Information System database (U.S. Geological Survey, 2016) using the USGS site numbers in table 1.

Water temperature varied among sites and was dependent on sampling date and time of day. Median water temperatures for the sites in the study ranged from 7.50 to 15.9 degrees Celsius $\left({ }^{\circ} \mathrm{C}\right)$. Water temperatures in 2013 during the fall samplecollection periods generally were lower than during the other 2 years. The lower temperatures and later fall sampling dates resulted in fewer fish collected at some sites when fish had already migrated to deeper waters.

Secchi-disk transparency also varied among sites during 2013-15. Secchi-disk transparency for nearshore sites in Little Vermilion, Crane, and Sand Point Lakes generally was measured at shallower depths (median values from 1.3 to $1.9 \mathrm{~m}$; table 3) than for nearshore sites in other lakes (median values from 2.0 to $2.5 \mathrm{~m}$, with the exception of Rainy Lake near Dove Bay, which had a median value of $1.5 \mathrm{~m}$ ). The median Secchi-disk transparency for midlake sites of Little Vermilion and Crane Lakes (1.7 to $1.8 \mathrm{~m}$ ) was shallower than for midlake sites at the other lakes (2.7 to $3.8 \mathrm{~m}$ ). The Secchi-disk transparency, or light penetration, in all six lakes is affected by staining associated with dissolved and organic materials (Payne, 1991; Kallemeyn and others, 2003).

Specific conductance and alkalinity values generally were highest in Kabetogama and Crane Lakes. Higher specific conductance and alkalinity values may be the result of clay deposits rich in soluble minerals found on the southern and western end of Kabetogama Lake (Kallemeyn and others, 2003). Specific conductance in Crane Lake is affected by the Vermilion River and other upstream sources. The median specific conductance values at all sampled sites ranged from 31 to 91 microsiemens per centimeter at 25 degrees Celsius $(\mu \mathrm{S} / \mathrm{cm}$ at $25^{\circ} \mathrm{C}$; table 3 ).

Median values for $\mathrm{pH}$ at all sampled sites ranged from 5.7 to 7.1. Most Voyageurs National Park lakes are slightly acidic, with the exception of Kabetogama Lake, which has a median $\mathrm{pH}$ of 7.1. Values of $\mathrm{pH}$ are important to this study because the mobility of methylmercury tends to increase in acidified waters (Wetzel, 2001).

Lake profiles of water temperature, specific conductance, $\mathrm{pH}$, and dissolved oxygen concentration were collected at midlake sites during sampling in 2013-15. Lake profile data are available from the USGS National Water Information System database (U.S. Geological Survey, 2016) using the USGS site numbers in table 1 for the midlake sites. In general, water 
Table 3. Median values of selected field properties in water samples, Voyageurs National Park, 2013-15.

[USGS, U.S. Geological Survey; ${ }^{\circ} \mathrm{C}$, degree Celsius; m, meter; $\mu \mathrm{S} / \mathrm{cm}$ at $25^{\circ} \mathrm{C}$, microsiemens per centimeter at 25 degrees Celsius; mg/L, milligram per liter; $\mathrm{CaCO}_{3}$, calcium carbonate; Minn., Minnesota; --, not analyzed]

\begin{tabular}{|c|c|c|c|c|c|c|c|c|}
\hline $\begin{array}{c}\text { Site } \\
\text { identifier } \\
\text { (fig. 1) }\end{array}$ & USGS site number & Site name & $\begin{array}{l}\text { Water } \\
\text { tempera- } \\
\text { ture }\left({ }^{\circ} \mathrm{C}\right)\end{array}$ & $\begin{array}{l}\text { Secchi } \\
\text { disk trans- } \\
\text { parency } \\
\text { (m) }\end{array}$ & $\begin{array}{c}\text { Specific } \\
\text { conduc- } \\
\text { tance, field } \\
(\mu \mathrm{S} / \mathrm{cm} \text { at } \\
\left.25^{\circ} \mathrm{C}\right)\end{array}$ & $\begin{array}{c}\text { Field } \\
\text { pH }\end{array}$ & $\begin{array}{c}\text { Dis- } \\
\text { solved } \\
\text { oxygen } \\
(\mathrm{mg} / \mathrm{L})\end{array}$ & $\begin{array}{c}\text { Acid } \\
\text { neutralizing } \\
\text { capac- } \\
\text { ity as } \mathrm{CaCO}_{3} \\
(\mathrm{mg} / \mathrm{L})\end{array}$ \\
\hline \multicolumn{9}{|c|}{ Midlake sites } \\
\hline 2 & 481730092283101 & $\begin{array}{l}\text { Crane Lake southwest of Indian } \\
\text { Island }\end{array}$ & 13.2 & 1.8 & 89 & 6.5 & 9.1 & 26 \\
\hline 3 & 482226092283301 & $\begin{array}{l}\text { Sand Point Lake below Harrison } \\
\text { Narrows near Crane Lake, } \\
\text { Minn. }\end{array}$ & 9.70 & 2.7 & 72 & 6.6 & 9.1 & 21 \\
\hline 6 & 483622092560701 & $\begin{array}{l}\text { Rainy Lake at Brule Narrows near } \\
\text { International Falls, Minn. }\end{array}$ & 15.3 & 3.8 & 48 & 6.9 & 9.4 & 16 \\
\hline 7 & 483713093035201 & $\begin{array}{l}\text { Rainy Lake east of Drywood } \\
\text { Island }^{1}\end{array}$ & 15.4 & 2.5 & 54 & -- & 9.2 & 16 \\
\hline \multicolumn{9}{|c|}{ Nearshore sites } \\
\hline 8 & 481818092254201 & $\begin{array}{l}\text { Little Vermilion Lake above Little } \\
\text { Vermilion Narrows }\end{array}$ & 11.1 & 1.3 & 36 & 6.6 & 10.2 & 10 \\
\hline 9 & 481751092251901 & $\begin{array}{l}\text { Little Vermilion Lake, northwest } \\
\text { side }\end{array}$ & 11.3 & 1.8 & 31 & 6.4 & 9.9 & 14 \\
\hline 10 & 481827092285401 & $\begin{array}{l}\text { Crane Lake, north shore, near } \\
\text { Indian Island }\end{array}$ & 10.7 & 1.6 & 89 & 6.5 & 9.5 & 28 \\
\hline 14 & 482241092311501 & Sand Point Lake at Grassy Bay & 10.6 & 1.9 & 69 & 6.0 & 10.1 & 21 \\
\hline 15 & 482553092404801 & $\begin{array}{l}\text { Namakan Lake at Wolf Pack } \\
\text { Islands }\end{array}$ & 15.0 & 2.4 & 49 & 7.0 & 9.5 & 15 \\
\hline 16 & 482541092411601 & $\begin{array}{l}\text { Namakan Lake at McManus } \\
\text { Island }\end{array}$ & 14.9 & 2.5 & 49 & 6.9 & 9.2 & 14 \\
\hline 17 & 482556092521601 & $\begin{array}{l}\text { Kabetogama Lake at Blind Ash } \\
\text { Bay }\end{array}$ & 14.5 & 2.0 & 88 & 7.1 & 9.2 & 36 \\
\hline 18 & 482603092490501 & $\begin{array}{l}\text { Kabetogama Lake below Boblore } \\
\text { Island }\end{array}$ & 15.2 & 2.3 & 73 & 6.8 & 8.3 & 27 \\
\hline 19 & 483549093033001 & $\begin{array}{l}\text { Rainy Lake, south side, near Dia- } \\
\text { mond Island }\end{array}$ & 14.7 & 2.0 & 52 & 7.0 & 9.4 & 17 \\
\hline 20 & 483615093054001 & Rainy Lake near Dove Bay & 14.4 & 1.5 & 52 & 7.0 & 9.9 & 11 \\
\hline
\end{tabular}

${ }^{1}$ Rainy Lake east of Drywood Island was sampled during the first year (2013) only. 
temperature, specific conductance, $\mathrm{pH}$, and dissolved oxygen concentrations either remained the same or decreased gradually with depth.

Temperature and dissolved oxygen profiles are important because they indicate vertical mixing of the lake. Anoxic conditions, or dissolved oxygen concentrations less than 5 milligrams per liter (mg/L), occurred near the bottom of Sand Point, Little Vermilion, and Crane Lakes. Sulfatereducing bacteria in anoxic zones can convert mercury to toxic methylmercury (Wetzel, 2001).

\section{Sulfate and Total Organic Carbon in Water Samples}

Total organic carbon and dissolved sulfate were analyzed in samples collected during 2013-15 for the midlake sites and the nearshore sites. Median concentrations for the three sampling events are provided in table 4 , and individual sample concentrations are available from the USGS National Water Information System database (U.S. Geological Survey, 2016) using the USGS site numbers in table 1.

Sulfur is widely distributed in igneous and sedimentary rocks (Hem, 1992). When the rocks are weathered and in contact with oxygenated water, sulfur is oxidized to sulfate. Deposition of sulfate sourced from fossil fuel combustion, also is a source of sulfate to lakes in the region (Nichols and McRoberts, 1986), although sulfate deposition to Voyageurs National Park has been declining since the 1980s (Kallemeyn and others, 2003; Brigham and others, 2014). Sulfate concentrations in the water can affect mercury bioavailability to fish (Sorenson and others, 2005). Dissolved sulfate concentrations in Voyageurs National Park lakes ranged from 1.6 to $5.8 \mathrm{mg} / \mathrm{L}$. The lowest concentrations occurred in Little Vermilion Lake, and the highest concentrations occurred in Crane Lake. Generally, median concentrations of dissolved sulfate at the midlake sites were similar to concentrations at the nearshore sites.

Table 4. Median concentrations of dissolved sulfate, total organic carbon, total phosphorus, and chlorophyll $a$ in water samples, Voyageurs National Park, 2013-15.

[USGS, U.S. Geological Survey; mg/L, milligram per liter; $\mu \mathrm{g} / \mathrm{L}$, microgram per liter; Minn., Minnesota]

\begin{tabular}{|c|c|c|c|c|c|c|}
\hline $\begin{array}{c}\text { Site } \\
\text { identifier } \\
\text { (fig. 1) }\end{array}$ & USGS site number & Site name & $\begin{array}{l}\text { Dis- } \\
\text { solved } \\
\text { sulfate } \\
\text { (mg/L) }\end{array}$ & $\begin{array}{c}\text { Total } \\
\text { organic } \\
\text { carbon } \\
\text { (mg/L) }\end{array}$ & $\begin{array}{c}\text { Total } \\
\text { phosphorus } \\
\text { (mg/L) }\end{array}$ & $\begin{array}{c}\text { Chloro- } \\
\text { phyll } a \\
(\mu \mathrm{g} / \mathrm{L})\end{array}$ \\
\hline \multicolumn{7}{|c|}{ Midlake sites } \\
\hline 1 & 481648092242301 & Little Vermilion Lake east of Dovre Lake & 1.6 & 12.6 & 0.025 & 1.3 \\
\hline 2 & 481730092283101 & Crane Lake southwest of Indian Island & 5.7 & 11.7 & 0.019 & 3.1 \\
\hline 4 & 482616092372201 & Namakan Lake near Ray, Minn. & 2.7 & 10.7 & 0.010 & 1.8 \\
\hline 5 & 482731092574701 & Kabetogama Lake near Grave Island near Ray, Minn. & 2.3 & 9.90 & 0.034 & 4.3 \\
\hline 6 & 483622092560701 & $\begin{array}{l}\text { Rainy Lake at Brule Narrows near International Falls, } \\
\text { Minn. }\end{array}$ & 2.9 & 11.0 & 0.007 & 2.5 \\
\hline 9 & 481751092251901 & Little Vermilion Lake, northwest side & 1.6 & 11.5 & 0.027 & 2.3 \\
\hline 10 & 481827092285401 & Crane Lake, north shore, near Indian Island & 5.8 & 11.7 & 0.019 & 2.1 \\
\hline 11 & 481835092294401 & Crane Lake, northwest end, near Crane Lake, Minn. & 5.7 & 12.0 & 0.021 & 1.1 \\
\hline 12 & 482006092283301 & Sand Point Lake, west side, near Mukooda Lake & 4.5 & 12.4 & 0.015 & 1.8 \\
\hline 13 & 482416092290401 & Sand Point Lake at Swansons Bay & 4.1 & 12.4 & 0.019 & 2.5 \\
\hline 14 & 482241092311501 & Sand Point Lake at Grassy Bay & 4.0 & 11.8 & 0.021 & 1.5 \\
\hline 15 & 482553092404801 & Namakan Lake at Wolf Pack Islands & 2.8 & 10.6 & 0.010 & 2.0 \\
\hline 16 & 482541092411601 & Namakan Lake at McManus Island & 2.8 & 9.30 & 0.011 & 1.3 \\
\hline
\end{tabular}


Total organic carbon (TOC) is the approximation of the amount of organic material in a water body (Hem, 1992). The concentrations of organic matter affects mercury methylation. Research has indicated that concentrations of total mercury and methylmercury in lakes increase directly with increasing concentrations of dissolved organic carbon (DOC; Wetzel, 2001). The median TOC concentrations in Voyageurs National Park lakes sampled for this study ranged from 9.30 to $12.9 \mathrm{mg} / \mathrm{L}$. The lowest median TOC concentrations occurred in Namakan Lake, and the highest median TOC concentrations occurred in Sand Point Lake. There was very little difference in median values between midlake and nearshore sites.

\section{Total Phosphorus, Chlorophyll $a$, and Trophic Status}

Phosphorus can be used in the calculation of a lake's trophic status (Carlson, 1977), and variability in trophic status can correlate with mercury levels in fish (Wiener and Spry, 1996). Algal abundance has been associated with total phosphorus concentrations (Wetzel, 2001) and large inputs of phosphorus into the aquatic environment may cause excessive algal growth. Median concentrations of total phosphorus and chlorophyll $a$ for the 7 midlake sites and the 13 nearshore sites for the three sampling events are provided in table 4, and individual sample concentrations are available from the USGS National Water Information System database (U.S. Geological Survey, 2016) using the USGS site numbers in table 1.

Median values of total phosphorus for lakes sampled in this study ranged from 0.007 to $0.035 \mathrm{mg} / \mathrm{L}$. The largest median concentrations occurred in Kabetogama Lake, which has historically had some of the highest total phosphorus concentrations of the five large Voyageurs lakes (Payne, 2000; Christensen and others, 2004). Generally, the nearshore sites had median total phosphorus concentrations similar to concentrations at the corresponding midlake sites.

Water-level fluctuation may contribute to accelerated eutrophication (Hambright and others, 2004), which may affect a lake's trophic status. Trophic status, furthermore, was identified by Pickardt and others (2002) as a factor affecting mercury bioavailability to fish. Trophic status was compiled for several of the lakes in Voyageurs National Park before and after the 2000 Rule Curves were implemented (Christensen and Maki, 2015). Sand Point, Namakan, and Rainy Lakes had trophic state indices between 34 and 39, indicating oligotrophic conditions, whereas Kabetogama Lake and Black Bay in Rainy Lake had trophic state indices of 50 and 51, respectively, which placed them in the eutrophic category.

Median chlorophyll $a$ concentrations in samples collected for this study ranged from 0.9 to 9.0 micrograms per liter $(\mu \mathrm{g} / \mathrm{L})$. All lakes had median concentrations of $3.6 \mu \mathrm{g} / \mathrm{L}$ or less, with the exception of Kabetogama Lake where the median concentration was $4.3 \mu \mathrm{g} / \mathrm{L}$ at the midlake site and the median concentrations were 7.1 and $9.0 \mu \mathrm{g} / \mathrm{L}$ at the nearshore sites. Unlike sulfate, total organic carbon, and total phosphorus, median concentrations of chlorophyll $a$ varied between midlake sites and nearshore sites. This was not unexpected owing to the high spatial variability of chlorophyll $a$ concentrations known to occur in water bodies.

\section{Fish Mercury Body Burdens}

The sampling goal was to collect 20 young-of-the-year yellow perch at all near-shore sites during September or October of each year. In 2013 and 2014, fewer fish were collected at some sites, likely because the colder water temperatures caused fish to move to deeper water. In 2015, the sampling effort was moved 1 week earlier, and the minimum of 20 fish were captured at each site. Median concentrations (body burdens) of mercury by sample year for the 13 nearshore sites are provided in table 5, and individual fish sample concentrations are available from the USGS National Water Information System database (U.S. Geological Survey, 2016) using the USGS site numbers in table 1.

The median fish mercury concentrations were variable across the years (table 5). The lowest median concentrations occurred in 2015, and ranged from 14.7 ng/g at Kabetogama Lake below Boblore Island (USGS site number 482603092490501) to $77.0 \mathrm{ng} / \mathrm{g}$ at Crane Lake, north shore, near Indian Island (USGS site number 481827092285401). The highest concentrations occurred in 2014 and ranged from $27.1 \mathrm{ng} / \mathrm{g}$ at Kabetogama Lake at Blind Ash Bay (USGS site number 482556092521601) to 178 ng/g at Crane Lake, northwest end, near Crane Lake, Minn. (USGS site number 481835092294401). This is consistent with previous research, which indicated that Sand Point and Crane Lakes had the highest fish mercury concentrations of the six lakes (Larson and others, 2014). No individual fish mercury concentration exceeded the EPA criterion of $0.3 \mathrm{mg} / \mathrm{kg}$ (or $300 \mathrm{ng} / \mathrm{g}$; U.S. Environmental Protection Agency, 2001). However, smaller young-of-the-year fish have a relatively low trophic position compared to larger, older fish, and people generally consume adult fish. Despite not exceeding the EPA criterion, the mercury concentrations found in fish in this study are high for young-of-the-year fish when compared to other northern Minnesota lakes (Sorenson and others, 2005).

\section{Factors that May Affect Mercury Concentrations in Fish}

Accumulation of methylmercury in fish tissue is considered a substantial threat to the health of wildlife and humans (Scudder and others, 2009; Sunderland and others, 2014). Assessing the link between fish mercury concentrations and environmental factors is important because of the human and ecosystem health consequences associated with mercury contamination of fish. If there is a link between annual waterlevel fluctuations and mercury entering the aquatic food web each year, management action reducing the annual water-level 
Table 5. Median concentrations of total mercury in young-of-the-year yellow perch samples from nearshore sites, Voyageurs National Park, 2013-15.

[USGS, U.S. Geological Survey; FishHg, mercury concentration in young-of-the-year yellow perch; ng/g, nanogram mercury per gram wet weight; Minn., Minnesota; --, no data]

\begin{tabular}{|c|c|c|c|c|c|c|c|c|}
\hline \multirow{2}{*}{$\begin{array}{c}\text { Site } \\
\text { identifier } \\
\text { (fig. 1) }\end{array}$} & \multirow{2}{*}{ USGS site number } & \multirow{2}{*}{ Site name } & \multicolumn{2}{|c|}{2013} & \multicolumn{2}{|c|}{2014} & \multicolumn{2}{|c|}{2015} \\
\hline & & & $\begin{array}{c}\text { Number } \\
\text { of fish }\end{array}$ & $\begin{array}{l}\text { FishHg } \\
(\mathrm{ng} / \mathrm{g})\end{array}$ & $\begin{array}{c}\text { Number } \\
\text { of fish }\end{array}$ & $\begin{array}{c}\text { FishHg } \\
(\mathrm{ng} / \mathrm{g})\end{array}$ & $\begin{array}{c}\text { Number } \\
\text { of fish }\end{array}$ & $\begin{array}{l}\text { FishHg } \\
(\mathrm{ng} / \mathrm{g})\end{array}$ \\
\hline 8 & 481818092254201 & $\begin{array}{l}\text { Little Vermilion Lake above Little } \\
\text { Vermilion Narrows }\end{array}$ & 20 & 78.3 & 0 & -- & 20 & 47.8 \\
\hline 9 & 481751092251901 & Little Vermilion Lake, northwest side & 2 & 91.6 & 0 & -- & 20 & 60.8 \\
\hline 10 & 481827092285401 & $\begin{array}{l}\text { Crane Lake, north shore, near Indian } \\
\text { Island }\end{array}$ & 20 & 118 & 20 & 166 & 20 & 77.0 \\
\hline 11 & 481835092294401 & $\begin{array}{l}\text { Crane Lake, northwest end, near } \\
\text { Crane Lake, Minn. }\end{array}$ & 9 & 97.0 & 20 & 178 & 20 & 66.6 \\
\hline 12 & 482006092283301 & $\begin{array}{l}\text { Sand Point Lake, west side, near } \\
\text { Mukooda Lake }\end{array}$ & 20 & 133 & 20 & 162 & 20 & 71.3 \\
\hline 13 & 482416092290401 & Sand Point Lake at Swansons Bay & 20 & 76.1 & 6 & 121 & 20 & 78.0 \\
\hline 14 & 482241092311501 & Sand Point Lake at Grassy Bay & 20 & 80.1 & 20 & 162 & 20 & 67.4 \\
\hline 15 & 482553092404801 & Namakan Lake at Wolf Pack Islands & 20 & 64.0 & 20 & 59.9 & 20 & 26.4 \\
\hline 16 & 482541092411601 & Namakan Lake at McManus Island & 20 & 47.2 & 20 & 66.6 & 20 & 26.9 \\
\hline 17 & 482556092521601 & Kabetogama Lake at Blind Ash Bay & 20 & 37.1 & 20 & 27.1 & 20 & 15.0 \\
\hline 18 & 482603092490501 & $\begin{array}{l}\text { Kabetogama Lake below Boblore } \\
\text { Island }\end{array}$ & 20 & 34.8 & 20 & 62.2 & 20 & 14.7 \\
\hline 19 & 483549093033001 & $\begin{array}{l}\text { Rainy Lake, south side, near Dia- } \\
\text { mond Island }\end{array}$ & 7 & 47.7 & 20 & 71.6 & 20 & 28.5 \\
\hline 20 & 483615093054001 & Rainy Lake near Dove Bay & 0 & -- & 0 & -- & 20 & 24.8 \\
\hline
\end{tabular}

fluctuations may reduce mercury bioaccumulation in Voyageurs National Park fish.

The data from this study indicate that the three lakes with the highest mercury concentrations in fish-Little Vermilion, Crane, and Sand Point—had the lowest pH values, which may indicate that methylmercury is more mobile in acidic waters than neutral or alkaline waters as suggested by Wetzel (2001). These three lakes also had anoxic conditions (low dissolved oxygen) in water near the bottom of the lake, which is another condition that may be conducive to mercury methylation (Eckley and Hintlemann, 2006).

Studies have shown that $\mathrm{pH}$ and DOC have strong effects on the fate of mercury in an ecosystem. Increased uptake of methylmercury by diatoms has been shown to be correlated with increased DOC concentrations (Zhong and Wang, 2009). Other studies have shown that for the same species of fish taken from the same region, increasing the acidity of the water (decreasing $\mathrm{pH}$ ) and (or) the DOC content generally results in higher body burdens of mercury in fish (Krabbenhoft and Rickert, 1995), and the data presented in this report are consistent with those studies. The TOC concentrations for this study generally were highest in Little Vermilion, Crane, and Sand Point Lakes. Sulfate concentrations, however, were less consistent in their relation to fish mercury. Little Vermilion Lake had low sulfate concentrations, whereas Crane and Sand Point Lakes had higher sulfate concentrations. These are the three lakes with the highest mercury concentrations in fish.

Total phosphorus, chlorophyll $a$, and trophic state results also were less conclusive than $\mathrm{pH}$ and TOC results; however, the lake with the highest trophic state, Kabetogama Lake, generally had the lowest fish mercury concentrations, which is consistent with other studies, such as one by Pickhardt and others (2002), which showed that the more eutrophic lakes with algal blooms reduced the uptake of methylmercury in freshwater food webs. Another important consideration is that chlorophyll $a$ concentrations in samples collected during September or October may not be representative of chlorophyll $a$ concentrations in samples collected during the rest of the year.

This study, in combination with two on-going studies, increases the understanding of factors affecting young-of-theyear yellow perch in Rainy Lake and Namakan Reservoir. Research described by Kallemeyn and others (2009) created a digital elevation model for Rainy Lake and Namakan Reservoir that included both terrestrial topography and lake bathymetry. The digital elevation model allows for calculations of wet and dry land areas under the 1970 and 2000 Rule Curves at any time of year. With the added information provided by the digital elevation model, researchers can better understand 
wetland effects and the importance of the drying and rewetting of the perimeter of the lakes resulting from the water-level changes on mercury occurrence in fish. The digital elevation model, in combination with the existing USGS vegetation map of Voyageurs National Park (Hopp and others, 2000), provided the total area of connected wetlands under each set of rule curves.

Kallemeyn and others (2009) describe the output from a hydrologic modeling project for Rainy Lake and Namakan Reservoir, which can be used in conjunction with the results of this study. The output of the hydrologic modeling project includes a summary of lake-level conditions and fluctuations under the 1970 and 2000 Rule Curves. The hydrologic output was based on model runs using the same hydrologic input dataset, consisting of data (inflow) measured in this basin over the last 50-60 years, for each of the two rule curve scenarios; thus, this summary will allow a direct comparison of conditions under each set of rule curves for each water body (Rainy Lake and Namakan Reservoir), independent of the hydrologic differences that have existed before and after the 2000 Rule Curves were implemented. Output from the hydrologic modeling project can be used to test whether a water-level variable (for example, maximum water-level fluctuation within a year) is different in these water bodies under the 2000 Rule Curves than under the 1970 Rule Curves.

\section{Summary}

The U.S. Geological Survey, the National Park Service, and University of Wisconsin-La Crosse cooperated in a study to assess lake levels and water quality in comparison to mercury body burdens in young-of-the-year Perca flavescens (yellow perch) from six lakes in and near Voyageurs National Park in Minnesota. Additional environmental data were collected to evaluate their importance to the bioaccumulation of mercury in yellow perch.

Lake levels in Voyeaguers National Park are controlled by a series of dams for a variety of uses. Rule curves are requisite maximum and minimum water levels between which the private dam owners are required to operate. Despite maximum rule curve exceedances during extreme events at Namakan Reservoir during 2013-15, observed water-level fluctuations were significantly lower after 2000; however, water-level exceedances are important to this study because nearshore areas may become inundated and release methylmercury into the water.

Field properties and profiles of water quality indicate that Sand Point, Little Vermilion, and Crane Lakes were anoxic at times near the lake bottom. The presence of anoxic conditions is important because sulfate reducing bacteria may convert mercury to methylmercury.

Dissolved sulfur, total organic carbon, and total phosphorus were analyzed because of their possible correlation to methylmercury in fish. The median dissolved sulfate concentration was highest in Crane Lake, the median total organic carbon concentration was highest in Sand Point Lake, and the median total phosphorus concentration was highest in Kabetogama Lake, which is consistent with previous research. Previous research also showed the highest concentrations of mercury in young-of-the-year yellow perch occurred in Crane Lake and Sand Point Lake, and the lowest concentrations occurred in Kabetogama Lake.

Chlorophyll $a$ concentrations and the resulting trophic state of a lake can affect mercury bioavailability to fish. All lakes had median chlorophyll $a$ concentrations of 3.6 micrograms per liter $(\mu \mathrm{g} / \mathrm{L})$ or less with the exception of Kabetogama Lake, where median concentrations were $4.3 \mu \mathrm{g} / \mathrm{L}$ for the midlake sites and $7.1 \mu \mathrm{g} / \mathrm{L}$ and $9.0 \mu \mathrm{g} / \mathrm{L}$ for the nearshore sites. This is consistent with previous studies, which reported chlorophyll $a$ concentrations and corresponding trophic state indices that were higher in Kabetogama Lake than other Voyageurs National Park lakes. Fish mercury concentrations varied widely between years and among lakes. Fish mercury concentrations ranged from 14.7 nanograms per liter (ng/g) in fish samples from Kabetogama Lake in 2015 to $178 \mathrm{ng} / \mathrm{g}$ in fish samples from Crane Lake in 2014.

The data for this study can be used by the International Joint Commission and other researchers in decision-making models related to the effect of water-level changes on mercury body burdens in fish and other environmental factors. More specifically, the data can be combined with output from ongoing hydrologic modeling projects to test whether a waterlevel variable (for example, maximum water-level fluctuation within a year) is different in these water bodies under the 2000 Rule Curves than under the 1970 Rule Curves. 


\section{References Cited}

American Public Health Association, 1999, Standard methods for the examination of water and wastewater (21st ed.): Washington, D.C., American Public Health Association [variously paged].

Arar, E.J., and Collins G.B., 1997, U.S. Environmental Protection Agency Method 445.0 - In vitro determination of chlorophyll $a$ and pheophytin $a$ in marine and freshwater algae by fluorescence, revision 1.2: Cincinnati, Ohio, U.S. Environmental Protection Agency, National Exposure Research Laboratory, Office of Research and Development.

Brigham, M.E., Krabbenhoft, D.P., Olson, M.L., and DeWild, J.F., 2002, Methylmercury in flood-control impoundments and natural waters of Northwestern Minnesota, 199799: Water, Air, and Soil Pollution, v. 138, no. 1-4, p. 61-78. [Also available at http://dx.doi. org/10.1023/A:1015573621474.]

Brigham, M.E., Sandheinrich, M.B., Gay, D.A., Maki, R.P., Krabbenhoft, D.P., and Wiener, J.G., 2014, Lacustrine responses to decreasing wet mercury deposition ratesresults from a case study in northern Minnesota: Environmental Science \& Technology, v. 48, no. 11, p. 6115-6123. [Also available at http://dx.doi.org/10.1021/es500301a.]

Carlson, 1977, A trophic state index for lakes: Limnology and Oceanography, v. 22, no. 2, p. 361-369. [Also available at http://dx.doi.org/10.4319/lo.1977.22.2.0361.]

Christensen, V.G., and Maki, R.P., 2015, Trophic State in Voyageurs National Park lakes before and after implementation of a revised water-level management plan: Journal of the American Water Resources Association, v. 51, no. 1, p. 99-111. [Also available at http://dx.doi. org/10.1111/jawr.12234.]

Christensen, V.G., Maki, R.P., and Kiesling, R.L., 2011, Relation of nutrient concentrations, nutrient loading, and algal production to changes in water levels in Kabetogama Lake, Voyageurs National Park, northern Minnesota, 2008-09: U.S. Geological Survey Scientific Investigations Report 2011-5096, 50 p. [Also available at https://pubs.usgs.gov/ sir/2011/5096/.]

Christensen, V.G., Maki, R.P., and Kiesling, R.L., 2013, Evaluation of internal loading and water level changes: implications for phosphorus, algal production, and nuisance blooms in Kabetogama Lake, Voyageurs National Park, Northern Minnesota: Journal of Lake and Reservoir Management, v. 29 , p. 202-215. [Also available at http://dx.doi.org/10.10 80/10402381.2013.831148.]
Christensen, V.G., Payne, G.A., and Kallemeyn, L.W., 2004, Effects of changes in reservoir operations on water quality and trophic-state indicators in Voyageurs National Park, northern Minnesota, 2001-03: U.S. Geological Survey Scientific Investigations Report 2004-5044, 42 p. [Also available at http://pubs.usgs.gov/sir/2004/5044/.]

Clesceri, L.S., Eaton, A.D., Greenberg, A.E., eds., 1998, Standard methods for the examination of water and wastewater high-temperature combustion method 5310 B, in Standard methods for the examination of water and wastewater (20th ed.): American Waterworks Association and Water Environment Federation, 2-8 and 2-9, 1200 p.

Cole, G.F., 1979, Mission-oriented research in Voyageurs National Park: Proceedings of the Second Conference on Scientific Research in the National Parks, v. 7, p. 194-204.

Cole, G.F., 1982, Restoring natural conditions in a boreal forest park, in Sabol, K., ed., Transactions of the 47th North American Wildlife and Natural Resources Conference: Washington, D.C., Wildlife Management Institute, p. 411-420.

Depew, D.C., Basu, N., Burgess, N.M., Campbell, L.M., Evers, D.C., Grasman, K.A., and Scheuhammer, A.M., 2012, Derivation of screening benchmarks for dietary methylmercury exposure for the common loon (Gavia immer) rationale for use in ecological risk assessment: Environmental Toxicology and Chemistry, v. 31, no. 10, p. 2399-2407. [Also available at http://dx.doi.org/10.1002/etc.1971.]

Driscoll, C.T., Han, Y-J., Chen, C.Y., Evers, D.C., Lambert, K.F., Holsen, T.M., Kamman, N.C., and Munson, R.K., 2007, Mercury contamination in forest and freshwater ecosystems in the Northeastern United States: Bioscience, v. 57, p. 17-28. [Also available at http://dx.doi.org/10.1641/ B570106.]

Driscoll, C.T., Mason, R.P., Chan, H.M., Jacob, D.J., and Pirrone, N., 2013, Mercury as a global pollutant-Sources, pathways, and effects: Environmental Science and Technology, v. 47, no. 10, p. 4967-4983. [Also available at http:// dx.doi.org/10.1021/es305071v.]

Eckley, C.S., and Hintelmann, Holger, 2006, Determination of mercury methylation potentials in the water column of lakes across Canada: Science of the Total Environment, v. 368, p. 111-125.

Faveri, G., Kallemeyn, L., Maki. R., and Bomhof, J., 2015, Goals and performance of the IJC 2000 Rule Curves for Rainy Lake and Namakan Reservoir: Proceedings of the 2015 International Rainy- Lake of the Woods Watershed Forum (12th), March 11-12, 2015, in International Falls, Minnesota, p. 13. 
Fishman, M.J., and Friedman, L.C., eds., 1989, Methods for determination of inorganic substances in water and fluvial sediments: U.S. Geological Survey Techniques of WaterResources Investigations, book 5, chap. A1, p. 461-463. [Also available at https://pubs.usgs.gov/twri/twri5-a1/.]

Glazer, R., and Bohlander, D., 1978, Mercury levels in fish from eleven northeastern Minnesota lakes, 1977: Minnesota Department of Natural Resources, Division of Fish and Wildlife, Report 355.

Hambright, K.D., Eckert, W., Leavitt, P.R., and Schelske, C.L., 2004, Effects of historical lake level and land use on sediment and phosphorus accumulation rates in Lake Kinneret: Environmental Science and Technology, v. 38, no. 24, p. 6460-6467. [Also available at http://dx.doi.org/10.1021/ es0492992.]

Helsel, D.R., and Hirsch, R.M., 1992, Statistical methods in water resources: Amsterdam, Elsevier Science Publishers, $522 \mathrm{p}$.

Hem, J.D., 1992, Study and interpretation of the chemical characteristics of natural water (4th ed.): U.S. Geological Survey Water-Supply Paper 2254, 263 p.

Hopp, Kevin, Faber-Langendoen, Don, Lew-Smith, Michael, Aaseng, Norman, and Lubinski, Sara, 2000, USGS-NPS Vegetation Mapping Program, Voyageurs National Park, Minnesota: U.S. Department of the Interior, U.S. Geological Survey, $210 \mathrm{p}$.

International Joint Commission, 2001, Order prescribing method of regulating the levels of boundary waters: Washington, D.C., 16 p.

Kallemeyn, L.W., Cohen, Y., and Radomski, P., 1993, Rehabilitation of the aquatic ecosystem of Rainy Lake and Namakan Reservoir by restoration of a more natural hydrologic regime, in Hesse, L., Stalnaker, C.B., Benson, N.G., and Zuboy, J.R., eds., Proceedings of the Symposium on Restoration Planning for the Rivers of the Mississippi River Ecosystem: Washington, D.C., U. S. Department of the Interior, National Biological Survey, Biological Report 19, p. 432-448.

Kallemeyn, L.W., and Cole, G.F., 1990, Alternatives for reducing the impacts of regulated lake levels on the aquatic ecosystem of Voyageurs National Park, Minnesota: International Falls, Minnesota, U. S. National Park Service, Voyageurs National Park.
Kallemeyn, L., Darby, W.R., Eaton, E., Peterson, K., Smokorowski, K., and Van den Broeck, J., 2009, Plan of study for the evaluation of the IJC 2000 Order for Rainy and Namakan Lakes and Rainy River: Report prepared for the International Joint Commission by the 2000 Rule Curve Assessment Workgroup, 55+ p., accessed November 4, 2016, at http://www.ijc.org/rel/boards/rainylake/POS_Workgroup_Final_Report_To_IJC_30Jun09.pdf.

Kallemeyn, L.W., Holmberg, K.L., Perry, J.A., and Odde, B.Y., 2003, Aquatic synthesis for Voyageurs National Park: U.S. Geological Survey Information and Technology Report 2003-0001, 96 p. [Also available at http://www.cerc.usgs. gov/pubs/center/pdfdocs/ITR2003-0001.pdf.]

Knights, B.C., Wiener, J.G., Sandheinrich, M.B., Jeremiason, J.D., Kallemeyn, L.W., Rolfhus, K.R., and Brigham, M.E., 2005, Ecosystem factors influencing bioaccumulation of mercury from atmospheric deposition in interior lakes of the Voyageurs National Park, Minnesota: Final Report for the National Park Service, Midwest Region, Project Number 02-01: FY2002.

Krabbenhoft, D.P., and Rickert, D.A., 1995, Mercury contamination of aquatic ecosystems: U.S. Geological Survey Fact Sheet 216-95, version 1.0, accessed August 9, 2016, at http://pubs.usgs.gov/fs/1995/fs216-95/.

Larson, J.H., Maki, R.P., Knights, B.C., and Gray, B.R., 2014, Can mercury in fish be reduced by water level management? Evaluating the effects of water level fluctuation on mercury accumulation in yellow perch (Perca flavescens): Ecotoxicology, v.23, no. 8, p. 1555-1563. [Also available at http://dx.doi.org/10.1007/s10646-014-1296-5.]

Meyer, M.W., Evers, D.C., Hartigan, J.J., and Rasmussen, P.S., 1998, Patterns of common loon (Gavia immer) mercury exposure, reproduction, and survival in Wisconsin, USA: Environmental Toxicology and Chemistry, v. 17, no. 2, p. 184-190. [Also available at http://dx.doi.org/10.1002/ etc.5620170207.]

Minnesota Pollution Control Agency, 2016, Minnesota's Impaired Waters List, accessed November 7, 2016, at https://www.pca.state.mn.us/water/minnesotas-impairedwaters-list.

Morel, F.M.M., Kraepiel, A.M.L., and Amyot, M., 1998, The chemical cycle and bioaccumulation of mercury: Annual Review of Ecology and Systematics, v. 29, p. 543-566.

National Park Service, 2012, Mercury in fish at Voyageurs National Park: National Park Service Great Lakes Inventory and Monitoring Network Resource Brief, 1 p. 
Nichols, D.S., and McRoberts, R.E., 1986, Relations between lake acidification and sulfate deposition in Northern Minnesota, Wisconsin, and Michigan: Water, Air, and Soil Pollution, v. 31, no. 1, p. 197-206. [Also available at http:// dx.doi.org/10.1007/BF00630834.]

Payne, G.A., 1991, Water quality of lakes and streams in Voyageurs National Park, Northern Minnesota, 1977-84: U.S. Geological Survey Water-Resources Investigations Report 88-4016, 95 p.

Payne, G.A., 2000, Water quality of lakes in Voyageurs National Park, Northern Minnesota, 1999: U.S Geological Survey Water-Resources Investigations Report 00-4281, $12 \mathrm{p}$.

Pickhardt, P.C., Folt, C.L., Chen, C.Y., Klaue, Bjoern, and Blum, J.D., 2002, Algal blooms reduce the uptake of toxic methylmercury in freshwater food webs: Proceedings of the National Academy of Sciences, v. 99, no. 7, p. 4419-4423. [Also available at http://dx.doi.org/10.1073/ pnas.072531099.]

Pirrone, N., Cinnirella, S., Feng, X., Finkelman, R.B., Friedli, H.R., Leaner, J., Mason, R., Mukherjee, A.B., Stracher, G., Streets, D.G., and Telmer, K.K., 2009, Global mercury emissions to the atmosphere from natural and anthropogenic sources, chapter 1, in Pirrone, N., and Mason, R., eds., Mercury fate and transport in the global atmosphere-Emissions measurements and models: New York, Springer-Verlag, p. 3-50.

Sandheinrich, M.B., and Wiener, J.G., 2011, Methylmercury in freshwater fish-Recent advances in assessing toxicity of environmentally relevant exposures, in Beyer, W.N., and Meador, J.P., eds., Environmental contaminants in biotaInterpreting tissue concentrations (2d ed.): Boca Raton, Fla., Taylor and Francis Publishers p. 169-190.

Scudder, B.C., Chasar, L.C., Wentz, D.A., Bauch, N.J., Brigham, M.E., Moran, P.W., and Krabbenhoft, D.P., 2009, Mercury in fish, bed sediment, and water from streams across the United States, 1998-2005: U.S. Geological Survey Scientific Investigations Report 2009-5109, 74 p. [Also available at https://pubs.usgs.gov/sir/2009/5109/.]

Shubat, P., Staba, M., and Carpenter, H., 1995, Criteria used to issue fish consumption advice-1995 Minnesota fish consumption advisory: Minnesota Department of Health, HRA Series FSH-95-001 [variously paged].

Snodgrass, J.W., Jagoe, C.H., Bryan, A.L., Jr., Brant, H.A., and Burger, J., 2000, Effects of trophic status and wetland morphology, hydroperiod, and water chemistry on mercury concentrations in fish: Canadian Journal of Fisheries and Aquatic Sciences, v. 57, no. 1, p. 171-180. [Also available at http://dx.doi.org/10.1139/f99-199.]
Sorensen, J.A., Kallemeyn, L.W., and Sydor, M., 2005, Relationship between mercury accumulation in youngof-the-year yellow perch and water-level fluctuations: Environmental Science and Technology, v. 39, no. 23, p. 9237-9243. [Also available at http://dx.doi.org/10.1021/ es050471r.]

Sunderland, E.M., Wiener, J.G., and Brigham, M.E., 2014, Chapter 2, Why is mercury in fish a concern?, in Wentz, D.A., Brigham, M.E., Chasar, L.C., Lutz, M.A., and Krabbenhoft, D.P., Mercury in the Nation's streams - Levels, trend, and implications: U.S. Geological Survey Circular 1395, p. 11-20, accessed November 4, 2016, at http:// dx.doi.org/10.3133/cir1395.

U.S. Environmental Protection Agency, 2001, Water quality criterion for the protection of human health-Methylmercury: Washington, D.C., Office of Science and Technology, Office of Water, Final Report EPA-823-R-01-001.

U.S. Environmental Protection Agency, 2007, Method 7473, Mercury in solids and solutions by thermal decomposition, amalgamation, and atomic absorption spectrophotometry: Washington, D.C., U.S. Environmental Protection Agency.

U.S. Geological Survey, 2016, National Water Information System-Web interface: U.S. Geological Survey digital data, accessed November 4, 2016, at http://dx.doi. org/10.5066/F7P55KJN.

U.S. Geological Survey, variously dated, National field manual for the collection of water-quality data: U.S. Geological Survey Techniques of Water-Resources Investigations, book 9, chaps. A1-A10, accessed November 4, 2016, at http:// pubs.water.usgs.gov/twri9A.

Wagner, R.J., Boulger, R.W., Jr., Oblinger, C.J., and Smith, B.A., 2006, Guidelines and standard procedures for continuous water-quality monitors; Station operation, record computation, and data reporting (ver. 1.0): U.S. Geological Survey Techniques and Methods 1-D3, 96 p. [Also available at https://pubs.usgs.gov/tm/2006/tm1D3/.]

Wang, Qianrui, Kim, D., Dionysiou, D.D., Sorial, G.A., and Timberlake, D., 2004, Sources and remediation for mercury contamination in aquatic systems-a literature review: Environmental Pollution, v. 131, p. 323-336. [Also available at http://dx.doi.org/10.1016/j.envpol.2004.01.010.]

Watras, C.J., and Bloom, N.S., 1992, Mercury and methylmercury in individual zooplankton-implications for bioaccumulation: Limnology and Oceanography, v. 37, no. 6, p. 1313-1318. [Also available at http://dx.doi.org/10.4319/ lo.1992.37.6.1313.]

Wetzel, R.G., 2001, Limnology lake and river ecosystems (3d ed.): San Diego, Calif., Elsevier, 1,006 p. 
Wiener, J.G., Haro, R.J., Rolfhus, K.R., Sandheinrich, M.B., Bailey, S.W., Northwick, R.M., and Gostomski, T.J., 2013, Bioaccumulation of persistent contaminants in fish and larval dragonflies in six national park units of the western Great Lakes region, 2008-2009: Fort Collins, Colo., National Park Service, Natural Resource Data Series NPS/ GLKN/NRDS-2013/427, 112 p.

Wiener, J.G., Haro, R.J., Rolfhus, K.R., Sandheinrich, M.B., Bailey, S.W., Northwick, R.M., and Gostomski, T.J., 2016, Bioaccumulative contaminants in aquatic food webs in six national park units of the Western Great Lakes Region, 2008-2012: National Park Service Natural Resources Report NPS/GLKN/NRR—2016/1302, 293 p.

Wiener, J.G., Knights, B.C., Sandheinrich, M.B., Jeremiason, J.D., Brigham, M.E., Engstrom, D.R., Woodruff, L.G., Cannon, W.F., and Balogh, S.J., 2006, Mercury in soils, lakes, and fish in Voyageurs National Park (Minnesota) Importance of atmospheric deposition and ecosystem factors: Environmental Science and Technology, v. 40, p. 6261-6268. [Also available at http://dx.doi.org/10.1021/ es060822h.]
Wiener, J.G., and Spry, D.J., 1996, Toxicological significance of mercury in freshwater fish, in Beyer, W.N., Heinz, G.H., and Redmon, A.W., eds., Environmental contaminants in wildlife-Interpreting tissue concentrations: Boca Raton, Fla., Lewis Publishers, p. 297-339.

Wilde, F.D., and Radtke, D.B., 2005, Field measurements, in National Field Manual for the collection of waterquality data: U.S. Geological Survey Techniques of WaterResources Investigations, book 9, chap. A6 [various paged], accessed November 4, 2016, at http://pubs.water.usgs.gov/ twri9A6/.

Zhong, Huan, and Wang, W.-X., 2009, Controls of dissolved organic matter and chloride on mercury uptake by a marine diatom: Environmental Science and Technology, v. 43, no. 23, p. 8998-9003. [Also available at http://dx.doi. org/10.1021/es901646k.] 
Publishing support provided by:

Rolla Publishing Service Center

For more information concerning this publication, contact: Director, USGS Minnesota Water Science Center 2280 Woodale Drive

Mounds View, Minnesota 55112

(763) 783-3100

Or visit the Minnesota Water Science Center Web site at: https://mn.water.usgs.gov/ 



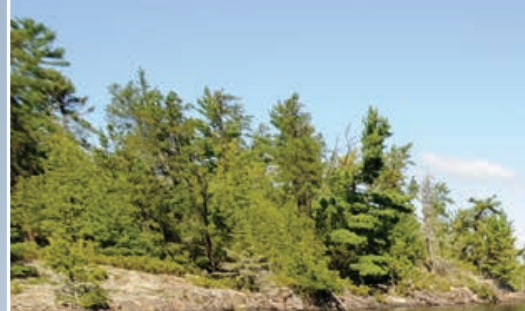

